
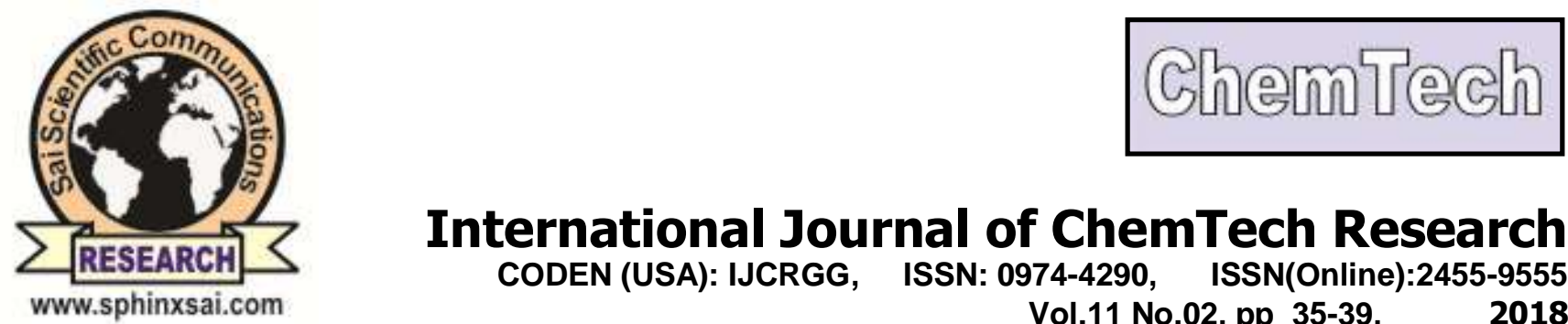

International Journal of ChemTech Research CODEN (USA): IJCRGG, ISSN: 0974-4290, ISSN(Online):2455-9555

Vol.11 No.02, pp 35-39,

2018

\title{
Comparative study of natural decolourizing agents for degradation of melanoidin present in biomethanated molasses spent wash
}

\author{
Monica Shukla ${ }^{1}$, Vivek Srivastava ${ }^{1}$, Ishwar Chandra ${ }^{2}$, Ajay Kumar*1 \\ 1Department of Biotechnology, Faculty of Engineering and Technology, Rama \\ University, Kanpur, Uttar Pradesh, India \\ ${ }^{2}$ Sir M Visvesvaraya Institute of Technology, Hunasamaranahalli, Bangalore, India
}

\begin{abstract}
Molasses Spent Wash (MSW) is pollution intensive waste water generated by ethanol distilleries. It retains very dark brown colour and severe pungent smell due to the presence of water soluble recalcitrant melanoidin pigment. In present laboratory scale study, removal of melanoidin from MSW was investigated using different cost effective decolorizing agents. The effect of various molasses concentration (10-100\% v/v) along with different combination of soil, bagasse, jagerry and fly ash was studied to estimate the removal efficiency. Results indicate that maximal reduction of colour removal of $85 \%$ was achieved by using combination of soil and bagasse at molasses concentration of $100 \%$ and contact time of 24 days.
\end{abstract}

Key words : Spent Wash; Soil, Bagasse, Fly Ash, Colour.

\section{Introduction}

A distilled beverage containing ethanol is produced by distillation of fermented grain, fruit, or vegetables. In Indian distillery sector ethanol is primarily produced by fermentation of molasses, a by-product of sugar industry which contain about 40-50\% sugar. There are about 295 distilleries in India which contribute for 2.7 billion litres of alcohol and generate 40 billion litres of wastewater annually ${ }^{1}$.Waste water which majorly consists of bottoms of distillation is known as spent wash (SW), it is nearly 15 times the alcohol produced $^{2}$ Spent wash should be treated before disposal and should possess the standards notified by Ministry of Environment and Forest (MoEF), Government of India vide GSR 176(E), April 2, 1996. SW should have pH between 5.5-9; suspended solids $100 \mathrm{mg} / \mathrm{L}$, and maximum BOD level of $30 \mathrm{mg} / \mathrm{L}$ for disposal into water courses and $100-120 \mathrm{mg} / \mathrm{L}$ for disposal on land. Many distilleries follow biological treatment via microbial activity for the mineralization and decolourization of spentwash ${ }^{3}$ as they are easy to operate, environment friendly and cost competitive alternative to chemical decomposition process ${ }^{4-8}$. Diverse microorganisms involved in decolourisation of spentwash are mentioned in Table 1. Even after this treatment the pollution potential of the SW is marginally reduced but the colour is still persistent. The colour is due to presence of brown polymers called melanoidins formed by the nonenzymatic browning reactions called Maillard aminocarbonyl reaction ${ }^{9}$ These compounds are highly recalcitrant and even toxic to many microorganisms used for

International Journal of ChemTech Research, 2018,11(02): 35-39.

DOI= http://dx.doi.org/10.20902/IJCTR.2018.110206 
wastewater treatment processes ${ }^{10}$. Due to dark colour, offensive odor and high COD these pose serious threat to soil and aquatic ecosystem ${ }^{11-12}$. Several authors have reported physico-chemical methods like coagulation and flocculation, oxidation, ultrafiltration, sonication etc. for treatment, but these methods require high reagent dosages and generate large amount of sludge ${ }^{11}$. Further to this, strict regulation of CPCB directs the distillery sector for zero-discharge, thereforemodern distilleries are adopting thermal incineration of SW. All these alternatives are not cost effective. Presently there is no sustainable solution for this problem. Through this paper we are reporting the possibility of decolourisation under static condition.

Table 1 Microorganisms capable of decolourizing distillery spent wash

\begin{tabular}{|c|c|c|c|}
\hline \multicolumn{2}{|r|}{ Microorganism } & Extent of & Reference \\
\hline \multicolumn{4}{|c|}{ A. Bacteria } \\
\hline 1. & Lactic acid bacteria & 70 & 13 \\
\hline 2. & P. fluorescens & 76 & 14 \\
\hline 3. & $\begin{array}{l}\text { Acetogenic bacterium } \\
\text { NOBP103 }\end{array}$ & 70 & 15 \\
\hline 4. & P. aeruginosa & 67.00 & 16 \\
\hline 5. & Pseudomonas sp. & 56.00 & 17 \\
\hline 6. & Citrobacter $s p$. & 19 & 18 \\
\hline 7. & Lactobacillus plantarum & 44 & 19 \\
\hline 8. & Pseudomonas aeruginosa & 92 & 20 \\
\hline 9. & Paracoccuspantotrophus & $81.2 \pm 2.43 \%$ & 21 \\
\hline \multicolumn{4}{|c|}{ B. Fungi } \\
\hline 10 & Aspergillus niger & 80 & 22 \\
\hline & Aspergillus niveus & 37 & 23 \\
\hline & Penicillium pinophilumTERI DB1 & 86 & 24 \\
\hline & Cladosporium cladosporioides & 52 & 25 \\
\hline
\end{tabular}

\section{Materials and Methods}

The molassesspent wash (MSW) after biomethanation was collected from Unnao Distilleries And Breweries Limited located near Kanpur city (Uttar Pradesh), India.The colour intensity of MSW was determined by UV- Visible spectrophotometer at wavelength of $475 \mathrm{~nm}$ ( $\lambda_{\max }$ of Melanoidin). MSW of different strength $\left(10-100 \% \mathrm{v} / \mathrm{v}\right.$ diluted using sterile distilled water of $\mathrm{pH} 7$, temperature $\left.37^{\circ} \mathrm{C}\right)$ was subjected to decolourisation using soil, bagasse, fly ash. All the samples were kept at room temperature under static condition for 24 days. Aliquots were withdrawn from each sample and centrifuged at 12,000rpm for 12 minutes. The supernatant obtained after the centrifugation was checked for absorbance. The extent of decolourisation was calculated by checking the difference in absorbance of the spentwash before and after treatment. The percentage of colour degradation is measured by:

$\%$ colour degradation $=[(\mathrm{Ci}-\mathrm{Cf}) * 100] / \mathrm{Ci}$

Where, $\mathrm{C} 0$ and $\mathrm{Cf}$ are the initial absorbance and final absorbance of the spent wash ${ }^{26-27}$.

\section{Result and Discussion}

The untreated MSW (100\%) showed the optical density of 1.26 (after 50X dilution) .The considerable colour reduction was observed when MSW was treated with soil, bagasse and fly ash (Table 2).

Colour removal of $64 \%$ was achieved for $20 \%$ MSW using soil alone (Figure1). Almost 69\% (Using soil and Fly Ash) and 46\% (Using soil and Jagerry) decolourization was obtained for $100 \%$ MSW and 50\% MSW respectively (Figure 3 and 4). In comparison with other carriers, maximum decolourization of $89 \%$ was measured for $100 \%$ MSW using soil with bagasse (Figure 2). Adikane H.V. ${ }^{28}$ reported decolourization of $69 \%$ using $10 \%(\mathrm{w} / \mathrm{v})$ soil and $12.5 \%$ (v/v) MSW after 7 days incubation. Optimized parameters including days -6 days, $\mathrm{pH}-6$, MSW $-12.5 \%$ and soil concentration $-40 \%$ were obtained for maximum decolourization. In 
another study where Fahy ${ }^{29}$ reporteddecolourization above $85 \%$ after 10 days incubation using 6.25\% MSW supplemented with $2.5 \%$ glucose.

Table 2- Decolourization (\%) of MSW treated with different natural carriers

\begin{tabular}{|c|l|l|l|l|}
\hline Concentration & $\begin{array}{l}\text { 1gm } \\
\text { Soil+10ml } \\
\text { Effluent }\end{array}$ & $\begin{array}{l}\text { 1gm Soil+ } \\
\mathbf{1 0 m l} \\
\text { Effluent+.5gm } \\
\text { Bagasse }\end{array}$ & $\begin{array}{l}\text { 1gm Soil+ 10ml } \\
\text { Effluent+.1gm } \\
\text { Jaggery }\end{array}$ & $\begin{array}{l}\text { 1gm Soil+ 10ml } \\
\text { Effluent+1gm } \\
\text { Flyash }\end{array}$ \\
\hline $\begin{array}{c}\text { Effluent Dilution } \\
(\boldsymbol{\%})\end{array}$ & Soil & Baggase + Soil & Jaggery+ Soil & Flyash+ Soil \\
\hline 10 & 53.23 & 66.94 & 0.81 & 55.65 \\
\hline 20 & 64.02 & 75.40 & 23.81 & 50.79 \\
\hline 30 & 25.97 & 74.55 & 24.68 & 18.96 \\
\hline 40 & 41.58 & 76.67 & 36.71 & 57.40 \\
\hline 50 & 37.36 & 85.16 & 46.15 & 53.02 \\
\hline 60 & 55.10 & 82.37 & 42.70 & 61.43 \\
\hline 70 & 38.46 & 82.47 & 29.13 & 62.30 \\
\hline 80 & 10.86 & 88.71 & 22.26 & 60.80 \\
\hline 90 & 7.20 & 85.60 & 14.96 & 57.82 \\
\hline 100 & 32.81 & 89.54 & 38.11 & 69.41 \\
\hline
\end{tabular}

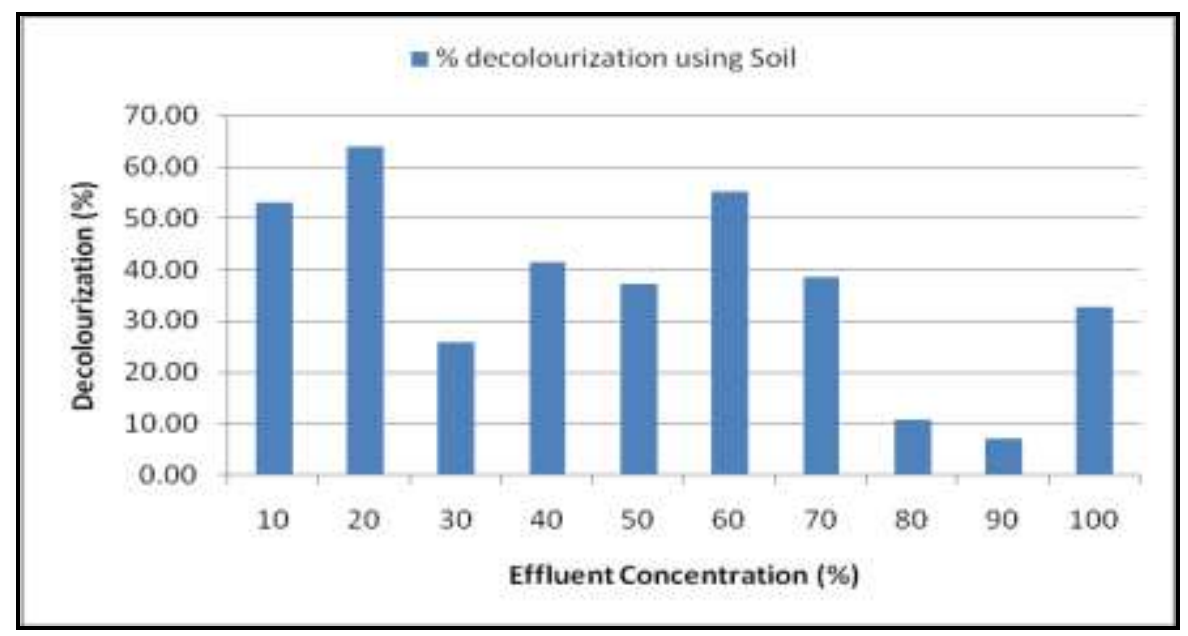

Figure 1.Decolourization pattern of MSW obtained after treatment with soil.

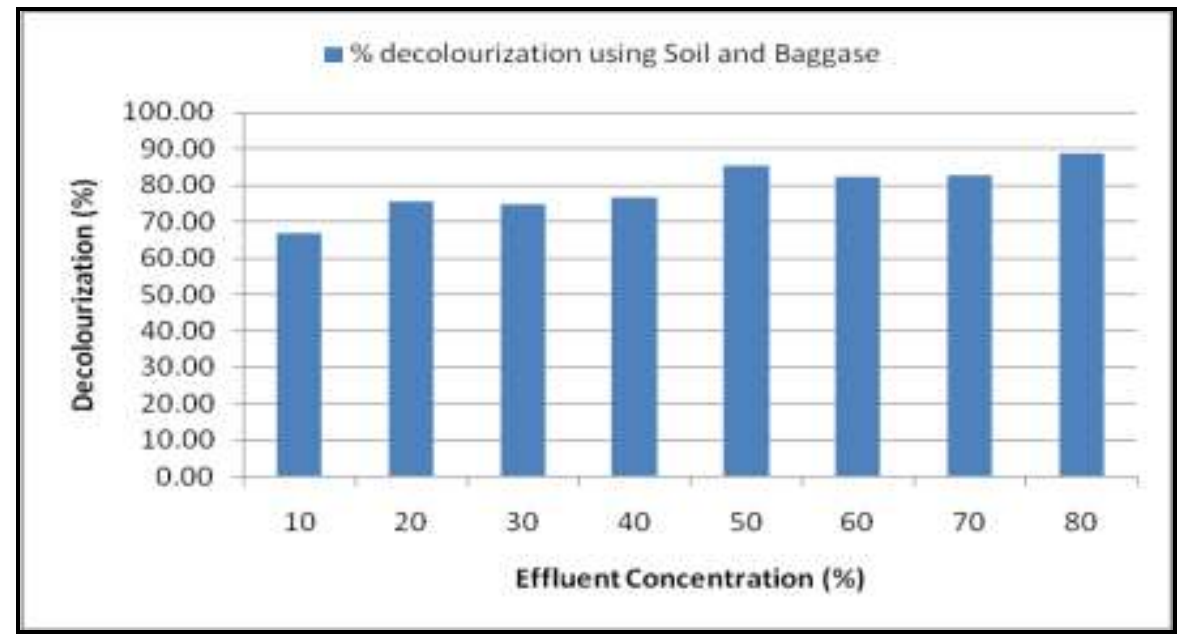

Figure 2.Decolourization pattern of MSW obtained after treatment with soil and Bagasse 


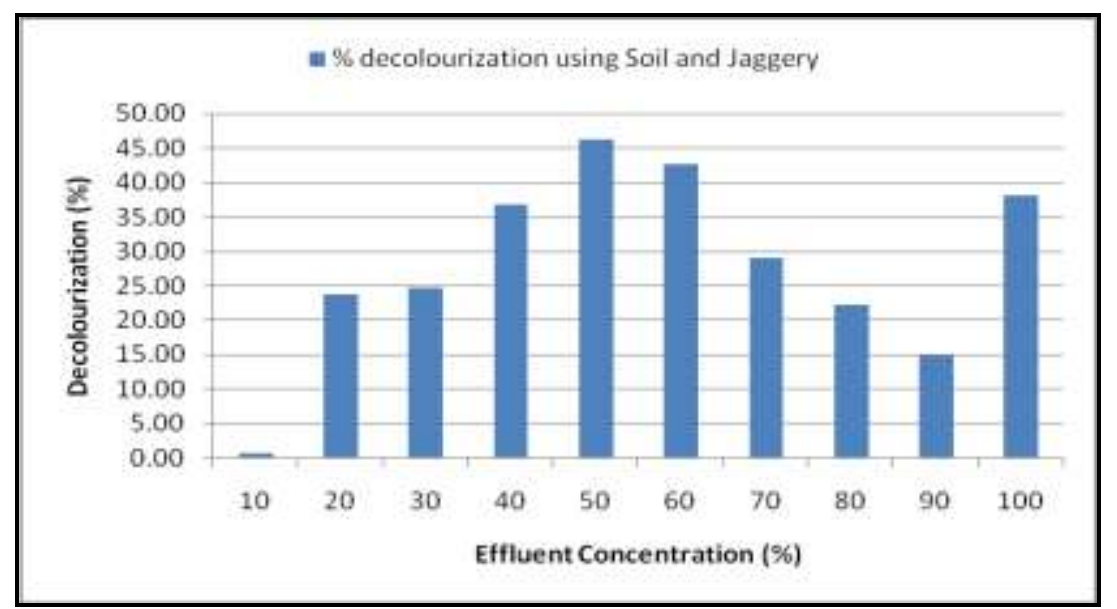

Figure 3.Decolourization pattern of MSW obtained after treatment with soil and Jaggery

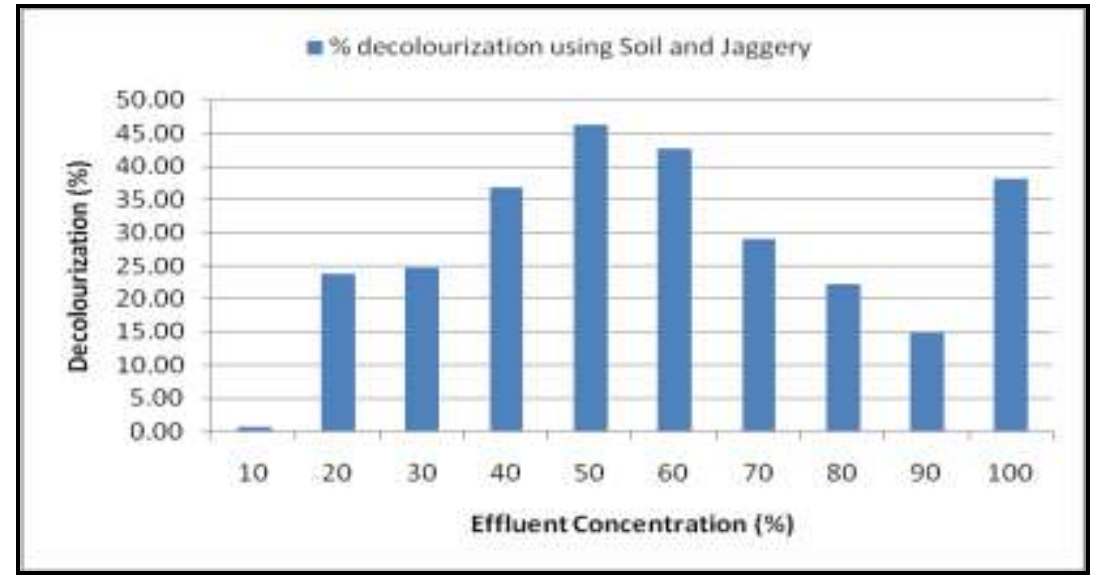

Figure 4.Decolourization pattern of MSW obtained after treatment with soil and Fly Ash.

\section{Conclusion}

On the basis of experimental result it can be concluded that treatment of MSW using soil with bagasse is one of the best combination than fly ash and jaggery as it resulted out the maximum decolourization of $89 \%$ after 24 days of incubation under static condition.

\section{References}

1. Naik N., Jagadeesh K.S., Noolvi M.N., Enhanced Degradation of Melanoidin and Caramel in Biomethanated Distillery Spentwash by Microorganisms Isolated from Mangroves. Iranica J Ener Environ.,2010,1, 347-351.

2. Guruswami R., Pollution control in distillery industry. National Seminar on Pollution Control in Sugar and Allied Industries, 1988.

3. Tamaki H., Taloaka S., Kishihara S. and Fujii S., Decolorization of cane sugar molasses by action of basiodiomycetes. J Japanese Soc Food Sci Tech, 1989, 36, 827-831.

4. Verma, P., Madamwar, D., Decolourization of synthetic dyes by a newly isolated strain of Serratiamarcescens. World Journal of Microbiology and Biotechnology,2003, 19, 615-618.

5. Moosvi, S., Keharia, H., Madamwar, D., Decolourization of textile dye Reactive Violet 5 by a newly isolated bacterial consortium RVM 11.1. World Journal of Microbiology and Biotechnology, 2005, 21, 667-672

6. Pandey, A., Singh, P., Iyengar, L., Bacterial decolorization and degradation of azo dyes. International Biodeterioration and Biodegradation, 2007, 59, 73-84.

7. Khalid, A., Arshad, M., Crowley, D.E., Accelerated decolorization of structurally different azo dyes by newly isolated bacterial strains. Applied Microbiology and Biotechnology,2008, 78, 361-369 
8. Dhanve, R.S., Shedbalkar, U.U., Jadhav, J.P., Biodegradation of diazo reactive dye Navy blue HE2R (reactive blue 172) by an isolated Exiguobacterium sp. RD3. Biotechnology and Bioprocess Engineering, 2008, 13, 53-60

9. Wedzicha, B. L., Kaputo, M. T., Melanoidins from glucose and glycine: Composition, characteristics and reactivity towards sulphite ion. Food Chemistry, 1992, 43, 359-367

10. Kitts D.D., Wu C.H., Stich H. F. and Powerte W.D., Effect of glucose-glycine maillard reaction products on bacterial and mammalian cells mutagenesis. J Agric Food Chem.,1993, 41,2353-2358

11. Mohana, S., Desai, C., Madamwar, D.,Biodegradation and decolourisation of anaerobically treated distillery spent wash by a novel bacterial consortium. Biores. Technol.,2007, 98, 333-339.

12. Kumar, P., Chandra, R., Decolourisation and detoxification of synthetic molasses melanoidins by individual and mixed cultures of Bacillus spp. Biores. Technol., 2006, 7, 2096-2102

13. Sharma N., Wati L. and Singh D., Bioremediation of anerobically digested molasses spentwash by lactic acid bacteria. Abstract presented in AMI Conference, Birla Institute of Scientifi c Research, Jaipur, 2000, 25-27, pp. 1

14. Jagroop D., Dalel S. and Poonam N.,Decolorization of molasses wastewater by cells of Pseudomonas fluorescens immobilized on porous cellulose carrier. Bioresource Technol., 2001, 78:111-114

15. Sirianuntapiboon S., Phothilangka P. and Ohmomo S., Decolorization of molasses wastewater by a strain No. BP103 of acetogenic bacteria. Biores Tech, 2004, 92,31-39

16. Sarayu M., Chirayu D. and Datta M., Biodegradation and decolorization of anerobically treated distillery spentwash by a novel bacterial consortium. Biores Tech, 2005, 98, 333-339

17. Chavan M.N., Kulkarni M.V., Zope V.P. and Mahulikar P.P.,Microbial degradation of melanoidins in distilleryspentwash by an indigenous isolate. Ind J Biotech, 2006, 5,416-421

18. JiranuntiponaS.,Deliab M. L., Albasib C., Damronglerdc S.,Chareonpornwattana S., Decolourization of molasses based distillery wastewater using a bacterial consortium, ScienceAsia,2009, 35, 332-339,

19. Krzywonos M., Seruga P., Decolorization of sugar beet molasses vinasse, a high-strength distillery wastewater, by lactic acid bacteria. Pol. J. Environ. Stud., 2012, 21, 4-11.

20. Charles D., Arivazhagan M., BalamuraliM. N. and DhivyaShanmugarajan:, Decolorization of Distillery Spent Wash Using Biopolymer Synthesized by Pseudomonas aeruginosa Isolated from Tannery Effluent, BioMed Research International, 2015, Volume 2015,9

21. Santal A. R. and Singh N., Biodegradation of Melanoidin from Distillery Effluent: Role of Microbes and Their Potential Enzymes. Biodegradation of Hazardous and Special Products, 2013, 5, 71-100.

22. Dhamankar V.S. and Patil P.U., Biochemical decolorization of biomethanated distillery spentwash. Proceedings of IntSoc cane Tech, 2001, 24, 329-333

23. Angayarkanni J., Palaniswamy M., Swaminathan K.,Biotreatment of distillery effluent using Aspergilusniveus. Bulletin Env Contamination Toxicol., 2003, 70, 268-27

24. Pant, D. and Adholeya A., Biological approaches for treatment of distillery wastewater: A review. Bioreso. Technol.,2007, 98, 2321-2334

25. Ravikumar R., Vasanthi N.S., Saravanan K., Biodegradation and decolorization of distillery spent wash with product release by a novel strain Cladosporiumcladosporioides: optimization and biokinetics. ChemBiochem J Q, 2013, 27(3), 373-383

26. David, C.,Narlawar, R., Arivazhagan, M., Performance evaluation of Moringaoleifera seed extract (MOSE) in conjunction with chemical coagulants fortreating distillery spent wash. J. Indian Chem. Eng. 2015, 1, 1-12

27. Raghukumar, C., Rivonkar, G., Decolorization of molasses spent wash by thewhite rot fungus Flavodonflavus, isolated from marine habitat. Appl. Microbiol. Biotechnol.,2001, 55, 510-514

28. Adikane H.V., Dange M.N., Selvakumari K., Optimization of anaerobicallydigested distillery molasses spent wash decolourization using soil asinoculum in the absence of additional carbon and nitrogen source.BioresTechnol, 2006, 97, 2131-2135.

29. Fahy, V., FitzGibbon, F. J., McMullan, G., Singh, D., Marchant, R.,Decolourization of molasses spent wash by Phanerochaetechrysosporium. Biotechnology Letters., 1997, 19, 97-99. 